\title{
Reversing multidrug resistance in breast cancer cells by silencing $A B C$ transporter genes with nanoparticle-facilitated delivery of target siRNAs
}

This article was published in the following Dove Press journal:

International Journal of Nanomedicine

4 June 2012

Number of times this article has been viewed

\author{
Yong Tsuey $\mathrm{Li}^{1}$ \\ Ming Jang Chua' \\ Anil Philip Kunnath' \\ Ezharul Hoque \\ Chowdhury ${ }^{1,2}$
}

'Faculty of Medicine and Health Science, International Medical University (IMU), Kuala Lumpur, Malaysia; ${ }^{2}$ Jeffrey Cheah School of Medicine and Health Sciences, Faculty of Medicine, Nursing and Health Sciences, Monash University, Kuala Lumpur, Malaysia
Correspondence: Ezharul Hoque Chowdhury

Faculty of Medicine and Health Science, International Medical University (IMU), No 126, Jalan I9/I55B, Bukit Jalil, 57000 Kuala Lumpur, Malaysia Tel +60355144978

Fax +60355146323

Email md.ezharul.hoque@monash.edu
Background: Multidrug resistance, a major impediment to successful cancer chemotherapy, is the result of overexpression of ATP-binding cassette (ABC) transporters extruding internalized drugs. Silencing of ABC transporter gene expression with small interfering RNA (siRNA) could be an attractive approach to overcome multidrug resistance of cancer, although delivery of siRNA remains a major hurdle to fully exploit the potential of siRNA-based therapeutics. Recently, we have developed $\mathrm{pH}$-sensitive carbonate apatite nanoparticles to efficiently carry and transport siRNA across the cell membrane, enabling knockdown of the cyclin B1 gene and consequential induction of apoptosis in synergy with anti-cancer drugs.

Methods and results: We report that carbonate apatite-mediated delivery of the siRNAs targeting $A B C G 2$ and $A B C B 1$ gene transcripts in human breast cancer cells which constitutively express both of the transporter genes dose-dependently enhanced chemosensitivity to doxorubicin, paclitaxel and cisplatin, the traditionally used chemotherapeutic agents. Moreover, codelivery of two specific siRNAs targeting $A B C B 1$ and $A B C G 2$ transcripts resulted in a more robust increase of chemosensitivity in the cancer cells, indicating the reversal of $A B C$ transporter-mediated multidrug resistance.

Conclusion: The delivery concept of multiple siRNAs against $A B C$ transporter genes is highly promising for preclinical and clinical investigation in reversing the multidrug resistance phenotype of breast cancer.

Keywords: carbonate apatite, siRNA, gene expression, transfection, breast cancer, ABC transporter, multidrug resistance, chemosensitivity

\section{Introduction}

Cancer is the leading cause of deaths worldwide with breast cancer being second in the list of cancer related deaths. ${ }^{1}$ Among all of the available treatment options, chemotherapy is the treatment of choice for advanced stage breast cancer that is refractory to hormonal therapy.,3 Although traditional breast cancer chemotherapy regimens include combinations of cyclophosphamide, methotrexate, and 5-flurouracil, ${ }^{4}$ anthracycline- and taxane-based chemotherapy is being commonly used nowadays for the treatment of breast malignancy due to its better performance in patient's overall survival rate. ${ }^{5-7}$ Though breast cancer is considered to be highly chemosensitive with response rates as high as $80 \%,{ }^{8}$ the majority of initially chemoresponsive tumours develop resistance to once effective chemotherapeutic agents. ${ }^{9}$ Therefore, a switch to other chemotherapy regimens is ineffective because of the tumour's cross-resistance to multiple structurally and functionally unrelated chemotherapy drugs. ${ }^{10}$

$\mathrm{ABC}$ transporter represents the key component of energy-dependent efflux transport system contributing to the development of multidrug-resistant phenotype in cancer. ${ }^{11}$ 
ABCB1 transporter or P-glycoprotein, the first cytotoxic drug efflux pump to be identified, ${ }^{12}$ functions by actively extruding drugs including anthracyclines, taxanes, and vinca alkaloids out of cancer cells, thus reducing intracellular drug concentration below the threshold level required for cell killing. ${ }^{10,11}$ The poor chemotherapy response in breast cancer is generally correlated to the extent of $A B C B 1$ gene expression. ${ }^{13-16}$ A second type of $\mathrm{ABC}$ transporter discovered in a multidrug resistant breast cancer cell line is ABCG2, ${ }^{17}$ though there are no conclusive data currently available to correlate its expression with chemotherapy efficacy in breast cancer. ${ }^{18}$ However, judging from the ability of ABCG2 transporter in extruding doxorubicin, a very commonly used anthracycline drug, ${ }^{19}$ it might be reasonable to correlate $\mathrm{ABCG} 2$ expression with development of clinical multidrug resistance in cancer.

Although low molecular weight pharmacologically active compounds have been developed to circumvent multidrugresistant phenotypes by either directly or indirectly modulating the $\mathrm{ABC}$ transporter efflux activity, ${ }^{20}$ the first generation modulators failed in clinical trials because of their inherent toxicities ${ }^{21}$ while the second generation molecules were associated with undesirable pharmacokinetic interactions. ${ }^{22,23}$ Thus, no drug has been clinically approved for the reversal of cancer multidrug resistance. ${ }^{24} \mathrm{~A}$ new promising approach to enhance chemosensitivity without undesirable side effects, other than the structure-based drug design, is to prevent the biosynthesis of $\mathrm{ABC}$ transporters by selectively inhibiting the expression of $\mathrm{ABC}$ transporters through gene silencing technologies. $^{25}$

In the last decade, ribozymes ${ }^{26-28}$ and antisense oligonucleotides ${ }^{29-31}$ were introduced to modulate cancer multidrug resistance through inhibition of $A B C$ transporter gene expression. Very recently, small interfering RNAs (siRNAs), a double-stranded RNA of between 21-28 nucleotides that selectively degrade mRNA and thus block production of a particular protein, ${ }^{32}$ have been applied in vitro for reversal of $\mathrm{ABC}$ transporter-mediated drug efflux by targeting both $\mathrm{ABCB} 1$ and $\mathrm{ABCG} 2$ transporters. A pioneering study using exogenous siRNA demonstrated suppression of ABCB1 expression in conjunction with reversal of doxorubicin
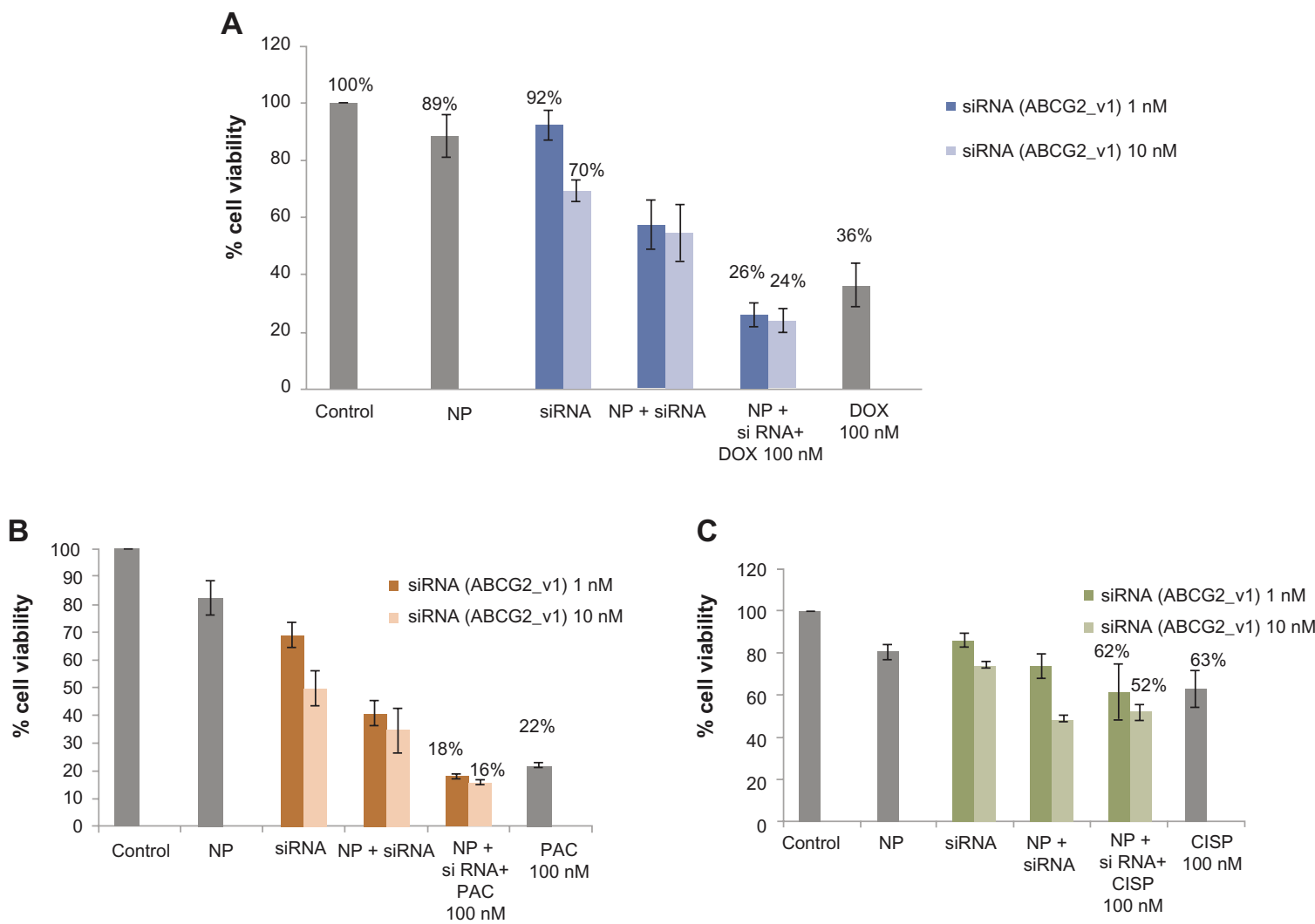

Figure I Effect of carbonate apatite-mediated delivery of ABCG2-targeted siRNA (ABCG2_vI) on MCF-7 cell viability in presence of traditionally used chemotherapeutic agents. Anti-ABC siRNA-carbonate apatite complexes were generated by mixing exogenously added $3 \mathrm{mM}$ calcium chloride in I mL bicarbonate-buffered DMEM ( $\mathrm{pH} 7.4$ ), followed by addition of anti-ABCG2 siRNA (I or $10 \mathrm{nM}$ ) and incubation at $37^{\circ} \mathrm{C}$ for 30 minutes. Supplementation of $10 \%$ FBS was followed by addition of $100 \mathrm{nM}$ of doxorubicin (A) or paclitaxel (B) or cisplatin (C).

Note: Transfection of MCF-7 cells was performed with the siRNA/nanoparticle complexes in presence of the free drugs for a consecutive period of 48 hours and viability of the cells was determined using MTT assay.

Abbreviations: NP, nanoparticles; siRNA, small interfering RNA; DOX, doxorubicin; PAC, paclitaxel; CISP, cisplatin. 
Table I Role of ABCG2 knockdown in enhancing cytotoxic effects of anti-cancer drugs at $100 \mathrm{nM}$

\begin{tabular}{|c|c|c|c|}
\hline \multirow{2}{*}{$\frac{\text { siRNA }}{A B C G 2}$} & \multicolumn{3}{|c|}{$\%$ enhancement of chemosensitivity } \\
\hline & Doxorubicin & Paclitaxel & Cisplatin \\
\hline & $100 \mathrm{nM}$ & $100 \mathrm{nM}$ & $100 \mathrm{nM}$ \\
\hline $\mathrm{I} \mathrm{nM}$ & $28 \%$ & $18 \%$ & $2 \%$ \\
\hline $10 \mathrm{nM}$ & $36 \%$ & $38 \%$ & $17 \%$ \\
\hline
\end{tabular}

Abbreviation: siRNA, small interfering RNA.

and paclitaxel resistance in human breast cancer cells. ${ }^{33}$ Reversal of multidrug-resistant ABCG2 phenotype was also investigated with a siRNA-mediated knockdown study in several human cancer cells. ${ }^{34}$

Currently, we have established $\mathrm{pH}$-sensitive carbonate apatite as a potential tool to efficiently deliver siRNA across the cell membrane and silence cyclin Bl gene transcript, thus inducing apoptosis of cervical cancer cells in synergy with anti-cancer drugs. ${ }^{35,36}$ Here, we reveal that carbonate apatite-mediated delivery of the siRNA targeting either $A B C G 2$ or $A B C B 1$ gene transcript in MCF-7, a human breast cancer cell line constitutively expressing $\mathrm{ABCG} 2$ and $\mathrm{ABCB} 1$ transporters, led to an increased chemosensitivity to doxorubicin, paclitaxel, and cisplatin, depending on the doses of the individual drug. Moreover, co-delivery of two specific siRNAs targeting $A B C B 1$ and $A B C G 2$ transcripts caused a dramatic enhancement of chemosensitivity activity in MCF-7 cells, indicating the reversal of $\mathrm{ABC}$ transportermediated multidrug resistance.

\section{Methods and materials Materials}

Dulbecco's modified Eagle medium (DMEM) was purchased from BioWhittaker (Walkersville, MD). DMEM powder, fetal bovine serum (FBS) and trypsin-ethylenediamine tetraacetate (trypsin-EDTA) were obtained from Gibco BRL (Carlsbad, CA). Calcium chloride dihydrate $\left(\mathrm{CaCl}_{2} \cdot 2 \mathrm{H}_{2} \mathrm{O}\right)$, sodium bicarbonate, diammineplatinum(11) dichloride, dimethyl sulphoxide (DMSO), doxorubicin hydrochloride, paclitaxel, and thiazolyl blue tetrazolium bromide (MTT) were from Sigma-Aldrich (St Louis, MO).

\section{siRNA design and sequence}

The siRNA sequence targeting ABCG2 (GenBank accession no NM_004827) and ABCB1 (GenBank accession no NM_000927) purchased from QIAGEN (Valencia, CA) correspond to coding regions of these genes. One target sequence (5'-CTGGTCTAATTTATTAATCTA-3') was

A

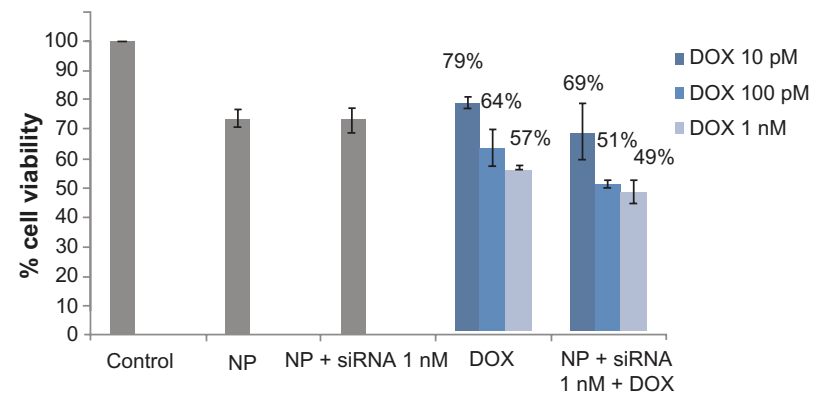

B

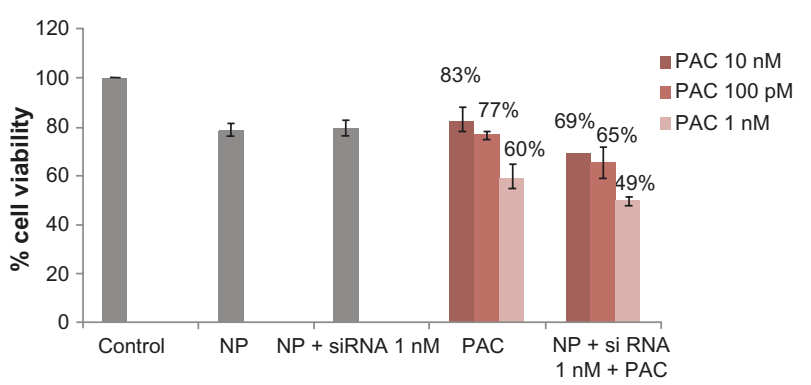

C

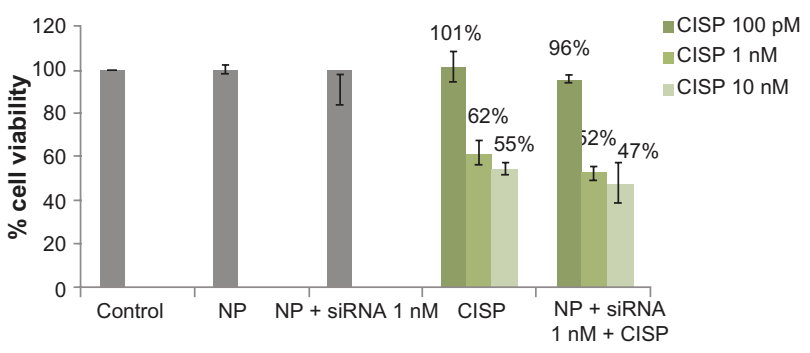

Figure 2 Effect of carbonate apatite-mediated delivery of ABCG2-targeted siRNA (ABCG2_vI) on MCF-7 cell viability in presence of low dose of traditionally used chemotherapeutic agents. Anti-ABC siRNA-carbonate apatite complexes were generated by mixing exogenously added $3 \mathrm{mM}$ calcium chloride in I mL bicarbonate-buffered DMEM ( $\mathrm{pH} 7.4$ ), followed by addition of anti-ABCG2 siRNA (I nM) and incubation at $37^{\circ} \mathrm{C}$ for 30 minutes. Supplementation of $10 \%$ FBS was followed by addition of $10 \mathrm{pM}$, 100 pM or I nM of doxorubicin (A) or paclitaxel (B) or 100 pM, I nM, 10 nM cisplatin (C).

Note: Transfection of MCF-7 cells was performed with the siRNA/nanoparticle complexes in presence of the free drugs for a consecutive period of 48 hours and viability of the cells was determined using MTT assay.

Abbreviations: NP, nanoparticles; siRNA, small interfering RNA; DOX, doxorubicin; PAC, paclitaxel; CISP, cisplatin. 
Table 2 Role of ABCG2 knockdown in enhancing cytotoxic effects of anti-cancer drugs at $10 \mathrm{pM}$ to $\mathrm{I} \mathrm{nM}$

\begin{tabular}{|c|c|c|c|c|c|c|c|c|c|}
\hline \multirow{3}{*}{$\frac{\overline{\text { siRNA }}}{\overline{A B C G 2}}$} & \multicolumn{9}{|c|}{$\%$ enhancement of chemosensitivity } \\
\hline & \multicolumn{3}{|c|}{ Doxorubicin } & \multicolumn{3}{|c|}{ Paclitaxel } & \multicolumn{3}{|c|}{ Cisplatin } \\
\hline & $10 \mathrm{pM}$ & $100 \mathrm{pM}$ & I nM & $10 \mathrm{pM}$ & $100 \mathrm{pM}$ & $\mathrm{I} n \mathrm{M}$ & $10 \mathrm{pM}$ & $100 \mathrm{pM}$ & I nM \\
\hline $\mathrm{InM}$ & $13 \%$ & $20 \%$ & $14 \%$ & $17 \%$ & $16 \%$ & $17 \%$ & $5 \%$ & $16 \%$ & $13 \%$ \\
\hline
\end{tabular}

Abbreviation: siRNA, small interfering RNA.

selected for ABCG2 (ABCG2_v1) and one (5'-GACAGAAAGCTTAGTACCAAA-3') for ABCB1 (ABCB1_v4). The 21-nucleotide siRNAs having a 3'-dTdT extension were chosen based on recommendations made by others. ${ }^{37,38}$ siRNA was supplied in lyophilised form and upon delivery, the siRNA (1 nmol) was reconstituted with RNase-free water provided by manufacturer to obtain a stock solution of $20 \mu \mathrm{M}$.

\section{Cell culture and seeding}

Human breast cancer cell line MCF-7 was grown in $25 \mathrm{~cm}^{2}$ culture flask in DMEM, supplemented with $10 \%$ heatinactivated FBS in a humidified atmosphere containing $5 \% \mathrm{CO}_{2}$ at $37^{\circ} \mathrm{C}$. Once the monolayer cells had reached $80 \%-90 \%$ confluency, the medium was removed and the cells were washed with phosphate-buffered saline (PBS).
Trypsin-EDTA was added to detach the cells from the flask and the suspended cells were collected in a fresh medium and transferred to new $25 \mathrm{~cm}^{2}$ flasks. The cells were then subcultured at densities of $1.0-5.0 \times 10^{5}$ cells $/ 10 \mathrm{~mL}$ every 3 to 4 days. Exponentially growing MCF-7 cells (log phase) were trypsinised and fresh medium was added to wash remaining cells from the bottom of the culture flask. Cell suspension was centrifuged at 10,000 rpm for 5 minutes and supernatant was discarded. Fresh medium was then added to resuspend the pellet. The cells were counted using hemocytometer and appropriate dilutions were made using culture medium to produce a cell suspension with a concentration of $5.0 \times$ $10^{4}$ cells $/ \mathrm{mL}$. One $\mathrm{mL}$ of the prepared cell suspension was subsequently added into each of the wells in 24-well plate and allowed to attach overnight at $37^{\circ} \mathrm{C}$ and $5 \% \mathrm{CO}_{2}$ before siRNA transfection.

A

B

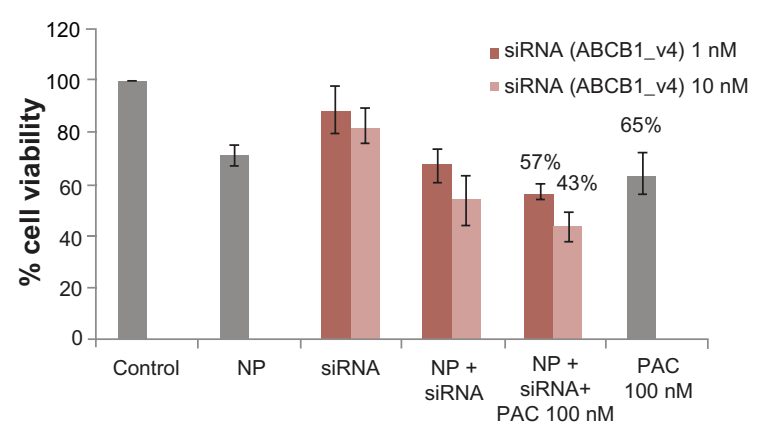

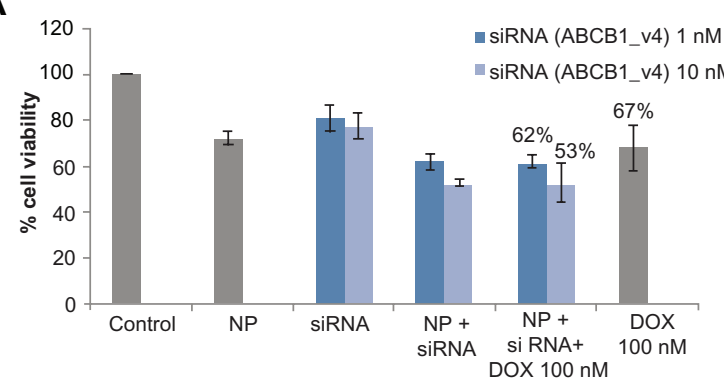

C

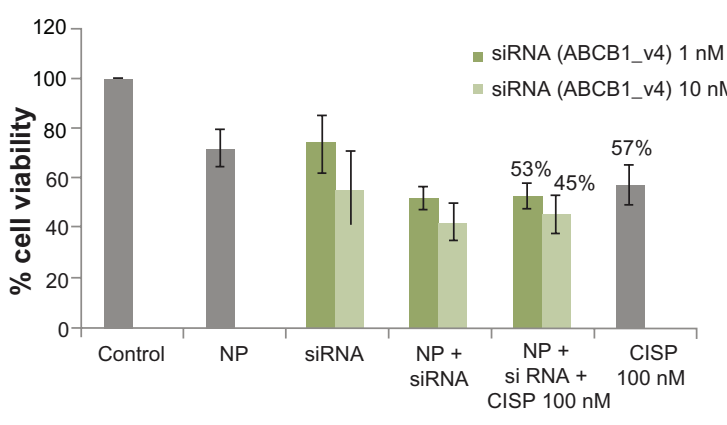

Figure 3 Effect of carbonate apatite-mediated delivery of $A B C B I$-targeted siRNA (ABCBI_v4) on MCF-7 cell viability in presence of traditionally used chemotherapeutic agents. Anti-ABC siRNA-carbonate apatite complexes were generated by mixing exogenously added $3 \mathrm{mM}$ calcium chloride in I mL bicarbonate-buffered DMEM (pH 7.4), followed by addition of anti-ABCBI siRNA ( 1 or $10 \mathrm{nM}$ ) and incubation at $37^{\circ} \mathrm{C}$ for 30 minutes. Supplementation of $10 \%$ FBS was followed by addition of $100 \mathrm{nM}$ of doxorubicin (A) or paclitaxel (B) or cisplatin (C).

Note: Transfection of MCF-7 cells was performed with the siRNA/nanoparticle complexes in presence of the free drugs for a consecutive period of 48 hours and viability of the cells was determined using MTT assay.

Abbreviations: NP, nanoparticles; siRNA, small interfering RNA; DOX, doxorubicin; PAC, paclitaxel; CISP, cisplatin. 
Table 3 Role of $A B C B \mid$ knockdown in enhancing cytotoxic effects of anti-cancer drugs at $100 \mathrm{nM}$

\begin{tabular}{llll}
\hline siRNA & \multicolumn{3}{l}{ \% Enhancement of chemosensitivity } \\
\hline ABCBI & Doxorubicin & Paclitaxel & Cisplatin \\
& $100 \mathrm{nM}$ & $100 \mathrm{nM}$ & $100 \mathrm{nM}$ \\
$\mathrm{I} \mathrm{nM}$ & $7 \%$ & $14 \%$ & $7 \%$ \\
$\mathrm{I} 0 \mathrm{nM}$ & $21 \%$ & $33 \%$ & $21 \%$ \\
\hline
\end{tabular}

\section{Generation of carbonate apatite nanoparticles containing siRNA and transfection of breast cancer cells}

On the day of siRNA transfection, $100 \mathrm{~mL}$ of DMEM was prepared using $1.35 \mathrm{~g}$ of DMEM powder and $0.37 \mathrm{~g}$ of sodium bicarbonate. $\mathrm{pH}$ of the prepared DMEM solution was adjusted to 7.4 using $0.1 \mathrm{M}$ hydrochloric acid. DMEM was then filtered using 0.2 a $\mu \mathrm{m}$ syringe filter in a laminar flow hood, followed by transferring $1 \mathrm{~mL}$ of the filtered medium into $1.5 \mathrm{~mL}$ microcentrifuge tubes. $3 \mu \mathrm{L}$ of $1 \mathrm{M}$ calcium chloride was then added into the microcentrifuge tubes, followed by addition of 1 or $10 \mathrm{nM}$ siRNA ${ }^{35,36}$ and incubation at $37^{\circ} \mathrm{C}$ for 30 minutes. After the incubation, $10 \%$ FBS was added into each microcentrifuge tube. Ten nM to $100 \mu \mathrm{M}$ of a drug (doxorubicin, paclitaxel, or cisplatin) prepared from serial dilution using $1 \mathrm{mM}$ stock solution was then added into the respective microcentrifuge tubes. Culture medium from the wells seeded one day before was aspirated and replaced with $1 \mathrm{~mL}$ of the prepared medium containing siRNA-loaded carbonate apatite nanoparticles and free drugs. Plates were then incubated at $37^{\circ} \mathrm{C}$ and $5 \% \mathrm{CO}_{2}$ for 2 consecutive days.

\section{Cell viability assessment with} 3-(4,5-dimethylthiazol-2-yl)-2,5diphenyltetrazolium bromide (MTT) assay Following two days of siRNA transfection, the fraction of viable MCF-7 cells was determined using MTT assay as previously described.$^{39}$ Briefly, $50 \mu \mathrm{L}$ of MTT $(5 \mathrm{mg} / \mathrm{mL}$ in PBS) was added aseptically into each of the wells in siRNA transfected plates, followed by incubation at $37^{\circ} \mathrm{C}$ and $5 \%$ $\mathrm{CO}_{2}$ for 4 hours. After the incubation period, medium containing MTT was aspirated and the purple formazan crystals at the bottom of each well were dissolved by mixing with
$300 \mu \mathrm{L}$ of DMSO solution. Absorbance of the resulting formazan solution was then determined spectrophotometrically at wavelength $595 \mathrm{~nm}$ using a microplate reader (Dynex Technologies Inc., Chantilly, VA) with reference to $630 \mathrm{~nm}$. Each experiment was performed in triplicate and the data were plotted as mean \pm standard deviation (SD) of three independent experiments.

\section{Results and Discussion}

Chemosensitivity enhancement in breast cancer cells with intracellularly delivered $A B C G 2$ transcript-targeting siRNA

Since $A B C$ transporter gene expression is essential in causing multidrug-resistant phenotype in breast cancer cells, knockdown of this gene might enhance sensitivity of the cancer cells towards chemotherapeutic agents, and possibly reverse cancer multidrug resistance. Therefore, MCF-7, the widely used human breast model cell line intrinsically expressing ABCG2 (alternatively called BRCP or breast cancer resistance protein), ${ }^{17}$ was transfected with the target siRNA/carbonate apatite complexes in presence or absence of traditionally used chemotherapeutic agents (doxorubicin, paclitaxel, or cisplatin) for a consecutive period of 48 hours prior to cell viability assessment by MTT assay. As shown in Figure 1A, while the viability of the cancer cells was reduced to $36 \%$ due to the potent cytoxicity of $100 \mathrm{nM}$ doxorubicin, the concerted effect of siRNA delivery and drug exposure resulted in $26 \%$ and $24 \%$ reduction in cell viability for $1 \mathrm{nM}$ and $10 \mathrm{nM}$ of siRNA initally used for complex formation, respectively. Thus, the combination of siRNA and doxorubicin killed a much higher number of cells than the drug and the siRNA alone, suggesting that silencing of the $A B C G 2$ gene might have inhibited to a significant extent the efflux of doxorubicin across the membrane, and raised intracellular concentration of the drug for effective killing of the cancer cells (Table 1). ABCG2 gene knockdown similarly accelerated chemosensitivity of paclitaxel $(100 \mathrm{nM})$ particularly at the higher dose of siRNA $(10 \mathrm{nM})$, while demonstrating an insignificant response with cisplatin (Figure 1B, Table 1). The apparent enhancement of chemosensitivity to cisplatin, as shown in Table 1, was virtually due to the silencing effect

Table 4 Role of $A B C B I$ knockdown in enhancing cytotoxic effects of anti-cancer drugs at 10 pM to I nM (doxorubicin and paclitaxel) and $100 \mathrm{pM}$ to $10 \mathrm{nM}$ (cisplatin)

\begin{tabular}{|c|c|c|c|c|c|c|c|c|c|}
\hline \multirow{3}{*}{$\frac{\text { siRNA }}{A B C B ~ I}$} & \multicolumn{9}{|c|}{$\%$ enhancement of chemosensitivity } \\
\hline & \multicolumn{3}{|c|}{ Doxorubicin } & \multicolumn{3}{|c|}{ Paclitaxel } & \multicolumn{3}{|l|}{ Cisplatin } \\
\hline & $10 \mathrm{pM}$ & $100 \mathrm{pM}$ & I nM & $10 \mathrm{pM}$ & $100 \mathrm{pM}$ & $\mathrm{I} \mathrm{nM}$ & $100 \mathrm{pM}$ & I nM & $10 \mathrm{nM}$ \\
\hline $\mathrm{InM}$ & $30 \%$ & $18 \%$ & $18 \%$ & $27 \%$ & $23 \%$ & $26 \%$ & $4 \%$ & $10 \%$ & $14 \%$ \\
\hline
\end{tabular}

Abbreviation: siRNA, small interfering RNA. 

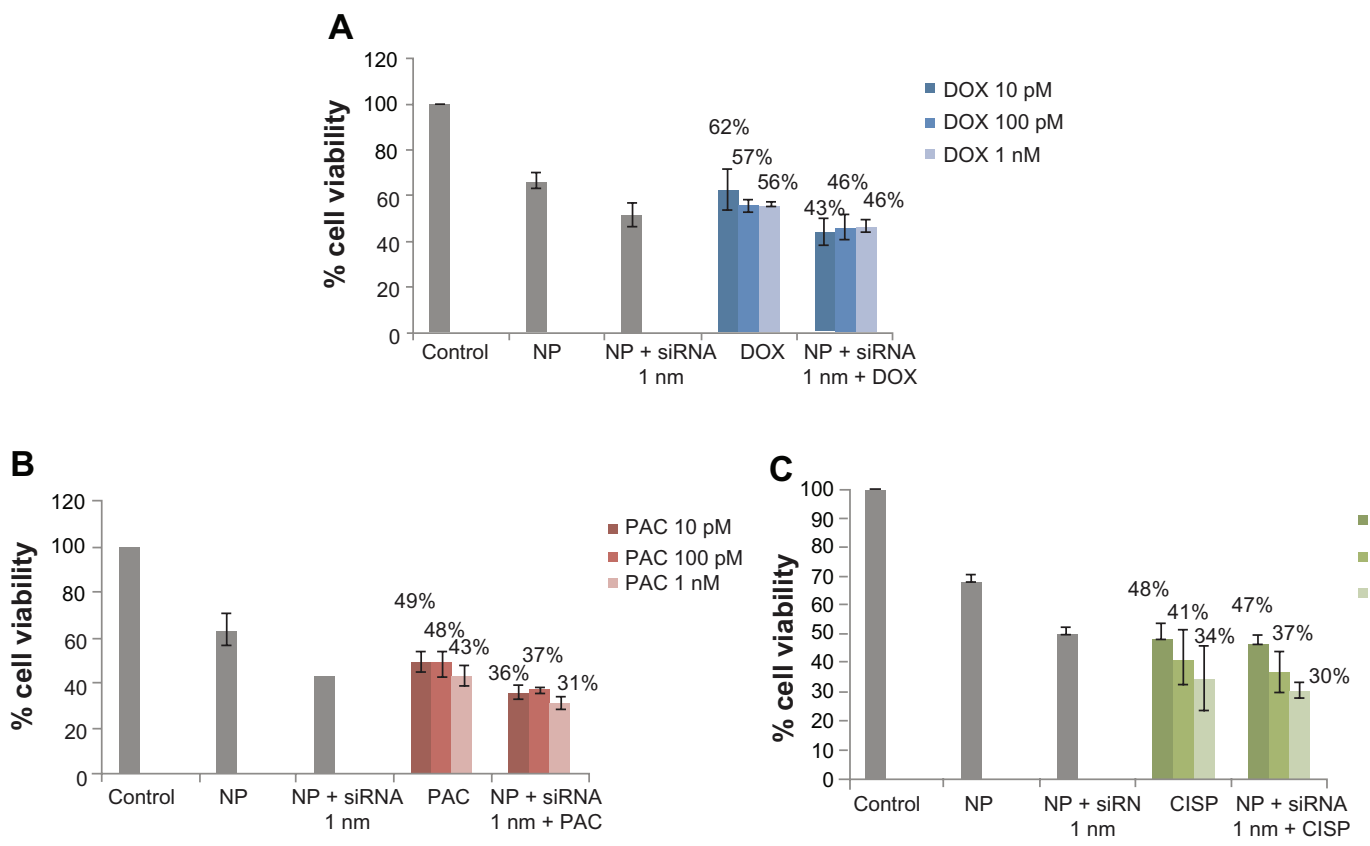

CISP $100 \mathrm{pM}$ CISP $1 \mathrm{nM}$ CISP $10 \mathrm{nM}$

Figure 4 Effect of carbonate apatite-mediated delivery of ABCBI-targeted siRNA (ABCBI_v4) on MCF-7 cell viability in presence of low dose of traditionally used chemotherapeutic agents. Anti-ABC siRNA-carbonate apatite complexes were generated by mixing exogenously added $3 \mathrm{mM}$ calcium chloride in I mL bicarbonate-buffered DMEM ( $\mathrm{pH} 7.4$ ), followed by addition of anti-ABCBI siRNA (I nM) and incubation at $37^{\circ} \mathrm{C}$ for 30 minutes. Supplementation of $10 \% \mathrm{FBS}$ was followed by addition of $10 \mathrm{pM}$, 100 pM or I nM of doxorubicin (A) or paclitaxel (B) or 100 pM, I nM, $10 \mathrm{nM}$ cisplatin (C).

Note: Transfection of MCF-7 cells was performed with the siRNA/nanoparticle complexes in presence of the free drugs for a consecutive period of 48 hours and viability of the cells was determined using MTT assay.

Abbreviations: NP, nanoparticles; siRNA, small interfering RNA; DOX, doxorubicin; PAC, paclitaxel; CISP, cisplatin.

of siRNA (Figure 1C) alone. Indeed, the decrease in viability of the cells treated with siRNA/nanoparticle complexes in comparison with those untreated or treated with nanoparticles alone indicates the role of $\mathrm{ABC}$ expression in delaying apoptosis of cancer cells. ${ }^{40-42}$
Based on the notion that anti-cancer drugs could dose-dependently influence the expression profile or susbtrate specificity of $\mathrm{ABC}$ transporters, a range of relatively lower concentrations of the drugs was investigated in the knockdown study of $\mathrm{ABC}$ transporters using $1 \mathrm{nM}$ of target

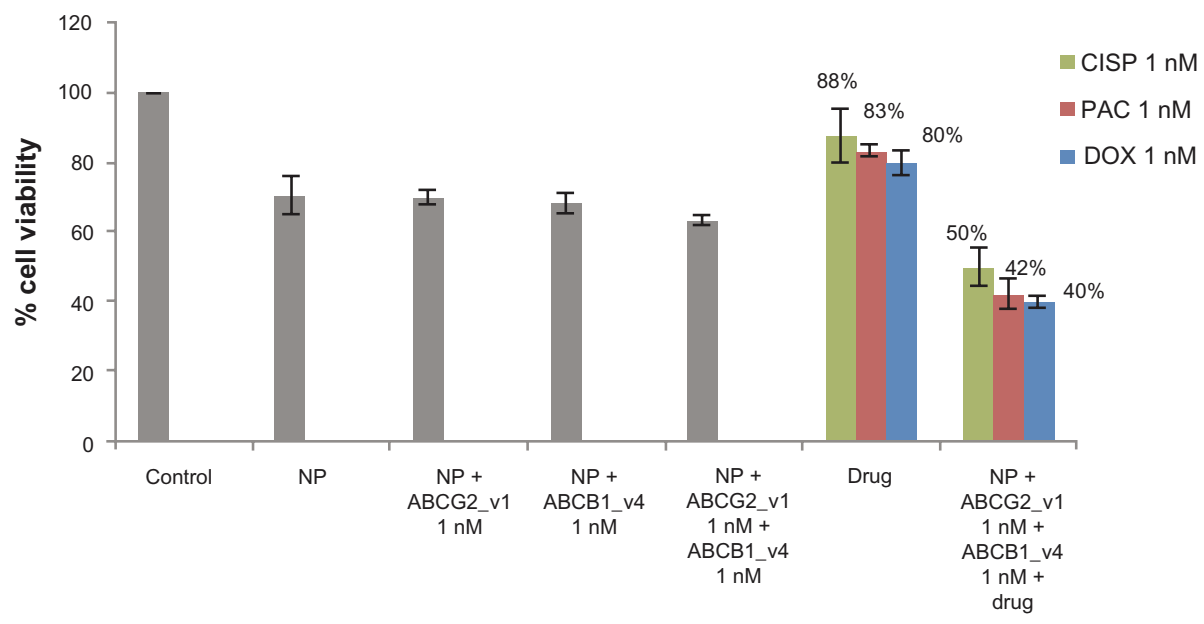

Figure 5 Combination effect of two siRNAs targeting $A B C G 2$ and $A B C B I$ ( $A B C G 2$ vI and $A B C B I$ v4 respectively) co-delivered with carbonate apatite nanoparticles on MCF-7 cell viability in presence of traditionally used chemotherapeutic agents. Anti-ABC siRNAs-carbonate apatite complexes were generated by mixing exogenously added $3 \mathrm{mM}$ calcium chloride in I $\mathrm{mL}$ bicarbonate-buffered DMEM ( $\mathrm{pH} 7.4$ ), followed by addition of anti-ABCG2 (I nM) and anti-ABCBI siRNA (I nM) and incubation at $37^{\circ} \mathrm{C}$ for 30 minutes. Supplementation of $10 \%$ FBS was followed by addition of I nM drug (doxorubicin, paclitaxel or cisplatin).

Note: Transfection of MCF-7 cells was performed with the siRNA/nanoparticle complexes in presence of the free drugs for a consecutive period of 48 hours and viability of the cells was determined using MTT assay.

Abbreviations: NP, nanoparticles; siRNA, small interfering RNA; DOX, doxorubicin; PAC, paclitaxel; CISP, cisplatin. 
Table 5 Role of $A B C G 2$ and $A B C B I$ knockdown in enhancing cytotoxic effects of anti-cancer drugs at I nM

\begin{tabular}{llll}
\hline siRNA & \multicolumn{3}{l}{$\%$ enhancement of chemosensitivity } \\
\cline { 2 - 4 } & Doxorubicin & Paclitaxel & Cisplatin \\
\hline$A B C G 2+A B C B I$ & $43 \%$ & $49 \%$ & $50 \%$ \\
I nM (each) & & & \\
$A B C G 2$ I nM & $14 \%$ & $17 \%$ & $16 \%$ \\
$A B C B$ I I nM & $18 \%$ & $26 \%$ & $10 \%$ \\
\hline
\end{tabular}

Abbreviation: siRNA, small interfering RNA.

siRNAs. As shown in Figure 2 and Table 2, with drug doses ranging from $10 \mathrm{pM}$ to $1 \mathrm{nM}$ for doxorubicin as well as paclitaxel and $100 \mathrm{pM}$ to $10 \mathrm{nM}$ for cisplatin, silencing of $A B C G 2$ gene expression resulted in significant enhancement of chemosensitivity towards doxorubicin and paclitaxel in all of the drug concentrations used, whereas a weak response to $100 \mathrm{pM}$ of cisplatin was observed probably due to the poor cytotoxic effect of cisplatin at the particular concentration. The finding thus suggests that the chemosensitivity of MCF-7 breast cancer cells due to the knockdown of $A B C G 2$ gene is virtually similar among the three drugs in respect to the maximum enhancement and dependent on the dose of the invidual drug.

\section{Chemosensitivity enhancement in breast cancer cells with intracellularly delivered $A B C B /$ transcript-targeting siRNA}

The enhancement of chemosensitivity to the popular anti-cancer drugs by virtue of silencing $A B C G 2$ gene expression triggered us to carry out a similar study in the same breast cancer cells using the siRNA targeting the gene of $A B C B 1$, the most extensively studied $A B C$ transporter involved in development of multi-drug resistance in various cancer cells including MCF-7. ${ }^{13}$ As shown in Figure 3, in synergy with $100 \mathrm{nM}$ of paclitaxel, anti-ABCB1 siRNA at both 1 and $10 \mathrm{nM}$ led to killing of much more cancer cells than the target siRNA ( 1 and $10 \mathrm{nM}$ ) or the drug $(100 \mathrm{nM})$ alone, resulting in 14\% and 33\% enhancement of chemosensitivity respectively. On the contrary, the apparent enhancement of chemosensitivity (to the same extent) towards both $100 \mathrm{nM}$ of doxorubicin and cisplatin following knockdown of ABCB1 transporter (Table 3) was solely due to the effect of gene silencing killing more cells than the individual drugs or the target siRNA alone (Figure 3). However, when the doses of the individual drugs were reduced to $10 \mathrm{pM}$ to $1 \mathrm{nM}$ for doxorubicin and paclitaxel, siRNA-mediated cleavage of $A B C B 1$ gene transcript surprisingly increased chemosensitivity towards each of the two drugs (Table 4) with demonstration of significantly higher level of cytotoxicity than siRNA or drugs alone (Figure 4), suggesting the broader substrate-specificity of $\mathrm{ABCB} 1$ transporter at lower concentrations of the individual cancer drugs. On ther other hand, the apparent increase in chemosensitivity for $100 \mathrm{pM}$ to $10 \mathrm{nM}$ of cisplatin was statistically insignificant, which is consistent with the fact that cisplatin is not a substrate for ABCB1.

Regardless of the type of siRNA (ABCG2 or ABCB1) used in this study, the enhancement of chemosensitivity after single siRNA treatment was only modest. This observation was similar to that made by other groups, where no complete reversal of cancer multidrug resistance was noted even at siRNA concentration as high as $200 \mathrm{nM} \cdot{ }^{33,43}$ Such incomplete reversal of cancer multidrug resistance may be attributed to the inherent nature of the target protein under study. Due to its long half-life (from 16 hours $^{44}$ to 72 hours ${ }^{45}$ ) and high cellular abundance, $\mathrm{ABC}$ transporter protein remains a challenging target for siRNA silencing. ${ }^{46}$

\section{Chemosensitivity enhancement in breast cancer cells with co-delivery of two siRNAs targeting $A B C G 2$ and $A B C B I$ gene transcripts}

Delivery of single siRNA targeting either ABCG2 or ABCB1 transporter with carbonate apatite nanoparticles demonstrated a modest $15 \%$ to $30 \%$ enhancement in chemosensitivity in MCF-7 cells (Tables 1-4). To explore whether the combined delivery of two specific siRNAs simultaneously targeting the two different transporters could further improve the chemosensitivity towards the anti-cancer drugs, MCF-7 cells were transfected with the siRNAs (at $1 \mathrm{nM}$ each) targeting the gene transcripts of $A B C G 2$ and $A B C B 1$ in presence of $1 \mathrm{nM}$ of the individual drugs. As shown in Figure 5, nanoparticlefacilitated intracellular delivery of single siRNA targeting a particular transporter killed fewer cells than co-delivery of the two target siRNAs, suggesting that both of the transporters, which are intrinsically expressed in MCF-7 cells, ${ }^{13,17}$ are important for survival of the cells. ${ }^{40-42}$ On the other hand, simultaneous delivery of the two target siRNAs into MCF-7 cells in presence of cisplatin, paclitaxel, or doxorubicin, was found to dramatically enhance cytotoxicity with enhancement of chemosensitivity by $50 \%, 49 \%$ and $43 \%$, respectively (Table 5), in comparison to the individual drugs and the siRNAs co-delivered without a drug. This suggests that both $\mathrm{ABCG} 2$ and $\mathrm{ABCB} 1$ are fully functional at a time in extruding any of those popular anti-cancer drugs from the cytoplasm of MCF-7 cells and inhibition or knockdown of a single transporter could only partly block the cellular efflux process, allowing drug efflux to continue through the other channel(s). 


\section{Conclusion}

Due to the heterogenous nature of tumours where several drug resistance mechanisms may coexist and simultaneously contribute to the development of cancer multidrug resistantphenotype, ${ }^{11}$ the use of siRNA combinations might represent a potential mechanism for circumventing this problem. Additionally, the concern about saturating the cellular RNA interference machinery by exogenous addition of two siRNAs may have been potentially overcome by combining siRNAs at the lowest possible concentration. Thus, the synergism achieved with combination of ABCG2 and ABCB1 targeting siRNAs would provide valuable insight for complete reversal of clinical cancer multidrug resistance otherwise deemed impossible to be achieved by currently available therapeutics.

\section{Disclosure}

The authors report no conflicts of interest in this work.

\section{References}

1. Moulder S, Hortobagyi GN. Advances in the treatment of breast cancer. Clin Pharmacol Ther. 2008;83(1):26-36.

2. Esteva FJ, Valero V, Pusztai L, Boehnke-Michaud L, Buzdar AU, Hortobagyi GN. Chemotherapy of metastatic breast cancer: what to expect in 2001 and beyond. Oncologist. 2001;6(2):133-146.

3. Hortobagyi GN. Treatment of breast cancer. NEngl J Med. 1998;339(18): 974-984.

4. Tubiana-Hulin M. How to maximize the efficacy of taxanes in breast cancer. Cancer Treat Rev. 2005;31 Suppl 4:S3-S9.

5. Fisher B, Redmond C, Wickerham DL, et al. Doxorubicin-containing regimens for the treatment of stage II breast cancer: the National Surgical Adjuvant Breast and Bowel Project experience. J Clin Oncol. 1989;7(5):572-582.

6. Nabholtz JM, Falkson C, Campos D, et al. Docetaxel and doxorubicin compared with doxorubicin and cyclophosphamide as first-line chemotherapy for metastatic breast cancer: results of a randomized, multicenter, phase III trial. J Clin Oncol. 2003;21(10):968-975.

7. Henderson IC, Berry DA, Demetri GD, et al. Improved outcomes from adding sequential paclitaxel but not from escalating doxorubicin dose in an adjuvant chemotherapy regimen for patients with node-positive primary breast cancer. J Clin Oncol. 2003;21(6): 976-983.

8. Burger H, Foekens JA, Look MP, et al. RNA expression of breast cancer resistance protein, lung resistance related protein, multi-drug resistance gene-1 in breast cancer: correlation with chemotherapeutic response. Clin Cancer Res. 2003;9(2):827-836.

9. Modok S, Mellor HR, Callaghan R. Modulation of multidrug resistance efflux pump activity to overcome chemoresistance in cancer. Curr Opin Pharmacol. 2006;6(4):350-354.

10. Ambudkar SV, Dey S, Hrycyna CA, Ramachandra M, Pastan I, Gottesman MM. Biochemical, cellular, and pharmacological aspects of the multidrug transporter. Annu Rev Pharmacol Toxicol. 1999;39: 361-398.

11. Szakács G, Paterson JK, Ludwig JA, Booth-Genthe C, Gottesman MM. Targeting multidrug resistance in cancer. Nat Rev Drug Discov. 2010;5(3):219-230.

12. Juliano RL, Ling V. A surface glycoprotein modulating drug permeability in Chinese hamster ovary cell mutants. Biochem Biophys Acta. 1976;455(1):152-162.
13. Trock BJ, Leonessa F, Clarke R. Multidrug resistance in breast cancer: a meta-analysis of MDR1/gp170 expression and its possible functional significance. J Natl Cancer Inst. 1977;89(13):917-931.

14. Leonessa F, Clarke R. ATP binding cassette transporters and drug resistance in breast cancer. Endocr Relat Cancer. 2003;10:43-73.

15. Kröger N, Achterrath W, Hegewisch-Becker S, Mross K, Zander AR. Current options in treatment of anthracycline-resistant breast cancer. Cancer Treat Rev. 1999;25(5):279-291.

16. Tsukamoto F, Shiba E, Taguchi T, et al. Immunohistochemical detection of P-glycoprotein in breast cancer and its significance as a prognostic factor. Breast Cancer. 1997;4(4):259-263.

17. Doyle LA, Yang W, Abruzzo LV, et al. A multidrug resistance transporter from human MCF-7 breast cancer cells. Proc Natl Acad Sci U S A. 1998;95(26):15665-15670.

18. Robey RW, To KK, Polgar O, et al. ABCG2: a perspective. Adv Drug Deliv Rev. 2009;61(1):3-13.

19. Noguchi K, Katayama K, Mitsuhashi J, Sugimoto Y. Functions of the breast cancer resistance protein (BCRP/ABCG2) in chemotherapy. $A d v$ Drug Deliv Rev. 2009;61(1):26-33.

20. Wu CP, Calcagno AM, Ambudkar SV. Reversal of ABC drug transportermediated multidrug resistance in cancer cells: evaluation of current strategies. Curr Mol Pharmacol. 2008;1(1):93-105.

21. Bartlett NL, Lum BL, Fisher GA, et al. Phase I trial of doxorubicin with cyclosporine as a modulator of multidrug resistance. J Clin Oncol. 1994;12(4):835-842.

22. Boote DJ, Dennis IF, Twentyman PR, et al. Phase I study of etoposide with SDZ PSC 833 as a modulator of multidrug resistance in patients with cancer. J Clin Oncol. 1996;14(2):610-618.

23. Giaccone G, Linn SC, Welink J, et al. A dose-finding and pharmacokinetic study of reversal of multidrug resistance with SDZ PSC 833 in combination with doxorubicin in patients with solid tumors. Clin Cancer Res. 1997;3(11):2005-2015.

24. Tiwari AK, Sodani K, Chen ZS. Current advances in modulation of $\mathrm{ABC}$ transporter-mediated multidrug resistance in cancer. Int J Toxicol Pharmcol Res. 2009;1:1-6.

25. Shi Z, Liang YJ, Chen ZS, et al. Reversal of MDR1/P-glycoproteinmediated multidrug resistance by vector-based RNA interference in vitro and in vivo. Cancer Biol Ther. 2006;5(1):39-47.

26. Liu C, Qureshi IA, Ding X, et al. Modulation of multidrug resistance gene (MDR-1) with antisense oligodeoxynucleotides. Clin Sci (Lond). 1996;91(1):93-98.

27. Alahari SK, DeLong R, Fisher MH, Dean NM, Viliet P, Juliano RL. Novel chemically modified oligonucleotides provide potent inhibition of P-glycoprotein expression. J Pharmacol Exp Ther. 1998;286(1): 419-428.

28. Stuart DD, Kao GY, Allen TM. A novel, long-circulating, and functional liposomal formulation of antisense oligodeoxynucleotides targeted against MDR1. Cancer Gene Ther. 2000;7(3):466-475.

29. Kobayashi H, Dorai T, Holland JF, Ohnuma T. Reversal of drug sensitivity in multidrug-resistant tumor cells by an MDR1(PGY1) ribozyme. Cancer Res. 1994;54(5):1271-1275.

30. Holm PS, Scanlon KJ, Dietel M. Reversion of multidrug resistance in the P-glycoprotein-positive human pancreatic cell line (EPP85181RDB) by introduction of a hammerhead ribozyme. $\mathrm{Br} J$ Cancer. 1994;70(2):239-243.

31. Gao Z, Fields JZ, Boman BM. Tumor-specific expression of antiMDR1 ribozyme selectively restores chemosensitivity in multidrugresistant colon-adenocarcinoma cells. Int J Cancer. 1999;82(3): 346-352.

32. Chowdhury EH. Strategies for tumor-directed delivery of siRNA. Expert Opin Drug Deliv. 2011;8(3):389-401.

33. Wu H, Hait WN, Yang JM. Small interfering RNA-induced suppression of MDR1 (P-glycoprotein) restores sensitivity to multidrug-resistant cancer cells. Cancer Res. 2003;63(7):1515-1519.

34. Ee PL, He X, Ross DD, Beck WT. Modulation of breast cancer resistance protein (BCRP/ABCG2) gene expression using RNA interference. Mol Cancer Ther. 2004;3(12):1577-1583. 
35. Stanislaus A, Hossain S, Chua MJ, et al. Fabrication and intracellular delivery of siRNA/carbonate apatite nano-composites for effective knockdown of cyclin B1 gene. Drugs and Therapy Studies. 2011;1:e8. DOI: $10.4081 /$ dts.2011.e8.

36. Hossain S, Stanislaus A, Chua MJ, et al. Carbonate apatite-facilitated intracellularly delivered siRNA for efficient knockdown of functional genes. J Control Release. 2010;147(1):101-108.

37. Elbashir SM, Harborth J, Lendeckel W, Yalcin A, Weber K, Tuschl T. Duplexes of 21-nucleotide RNAs mediate RNA interference in cultured mammalian cells. Nature. 2011;411(6836):494-498.

38. Harborth J, Elbashir SM, Bechert K, Tuschl T, Weber K. Identification of essential genes in cultured mammalian cells using small interfering RNAs. J Cell Sci. 2001;114(Pt 24):4557-4565.

39. Carmichael J, DeGraff WG, Gazdar AF, Minna JD, Mitchell JB. Evaluation of a tetrazolium-based semiautomated colorimetric assay: assessment of chemosensitivity testing. Cancer Res. 1987;47(4): 936-942.

40. Smyth MJ, Krasovskis E, Sutton VR, Johnstone RW. The drug efflux protein, P-glycoprotein, additionally protects drug-resistant tumor cells from multiple forms of caspase-dependent apoptosis. Proc Natl Acad Sci USA. 1998;95(12):7024-7029.
41. Johnstone RW, Cretney E, Smyth MJ. P-glycoprotein protects leukemia cells against caspase-dependent, but not caspase-independent, cell death. Blood. 1999;93(3):1075-1085.

42. Pallis M, Russell N. P-glycoprotein plays a drug-efflux-independent role in augmenting cell survival in acute myeloblastic leukemia and is associated with modulation of a sphingomyelin-ceramide apoptotic pathway. Blood. 2000;95(9):2897-2904.

43. Xu D, Kang H, Fisher M, Juliano RL. Strategies for inhibition of MDR1 gene expression. Mol Pharmacol. 2004;66(2):268-275.

44. Cohen D, Yang CP, Horwitz SB. The products of the mdrla and mdr1b genes from multidrug resistant murine cells have similar degradation rates. Life Sci. 1990;46(7):489-495.

45. Richert ND, Aldwin L, Nitecki D, Gottesman MM, Pastan I. Stability and covalent modification of P-glycoprotein in multidrug-resistant $\mathrm{KB}$ cells. Biochemistry. 1988;27(20):7607-7613.

46. Akhtar S, Benter IF. Nonviral delivery of synthetic siRNAs in vivo. J Clin Invest. 2007;117(12):3623-3632.
International Journal of Nanomedicine

\section{Publish your work in this journal}

The International Journal of Nanomedicine is an international, peerreviewed journal focusing on the application of nanotechnology in diagnostics, therapeutics, and drug delivery systems throughout the biomedical field. This journal is indexed on PubMed Central,

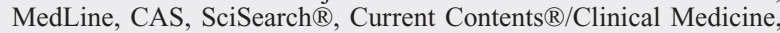

\section{Dovepress}

Journal Citation Reports/Science Edition, EMBase, Scopus and the Elsevier Bibliographic databases. The manuscript management system is completely online and includes a very quick and fair peer-review system, which is all easy to use. Visit http://www.dovepress.com/ testimonials.php to read real quotes from published authors. 